\title{
Meat and Fish Consumption, APCGene Mutations and hMLH1 Expression in Colon and Rectal Cancer: a Prospective Cohort Study (The Netherlands)
}

Citation for published version (APA):

Luchtenborg, M., Weijenberg, M. P., de Goeij, A. F., Wark, P. A., Brink, M., Roemen, G. M. J. M., Lentjes, M. H. F. M., de Bruine, A. P., Goldbohm, R. A., van 't Veer, P., \& van den Brandt, P. A. (2005). Meat and Fish Consumption, APCGene Mutations and hMLH1 Expression in Colon and Rectal Cancer: a Prospective Cohort Study (The Netherlands). Cancer Causes \& Control, 16(9), 1041-1054. https://doi.org/10.1007/s10552-005-0239-0

Document status and date:

Published: 01/01/2005

DOI:

10.1007/s10552-005-0239-0

Document Version:

Publisher's PDF, also known as Version of record

Document license:

Taverne

Please check the document version of this publication:

- A submitted manuscript is the version of the article upon submission and before peer-review. There can be important differences between the submitted version and the official published version of record.

People interested in the research are advised to contact the author for the final version of the publication, or visit the DOI to the publisher's website.

- The final author version and the galley proof are versions of the publication after peer review.

- The final published version features the final layout of the paper including the volume, issue and page numbers.

Link to publication

\footnotetext{
General rights rights.

- You may freely distribute the URL identifying the publication in the public portal. please follow below link for the End User Agreement:

www.umlib.nl/taverne-license

Take down policy

If you believe that this document breaches copyright please contact us at:

repository@maastrichtuniversity.nl

providing details and we will investigate your claim.
}

Copyright and moral rights for the publications made accessible in the public portal are retained by the authors and/or other copyright owners and it is a condition of accessing publications that users recognise and abide by the legal requirements associated with these

- Users may download and print one copy of any publication from the public portal for the purpose of private study or research.

- You may not further distribute the material or use it for any profit-making activity or commercial gain

If the publication is distributed under the terms of Article 25fa of the Dutch Copyright Act, indicated by the "Taverne" license above, 


\title{
Meat and fish consumption, $A P C$ gene mutations and hMLH1 expression in colon and rectal cancer: a prospective cohort study (The Netherlands)
}

\author{
Margreet Lüchtenborg ${ }^{1}$, Matty P. Weijenberg ${ }^{1, *}$, Anton F.P.M. de Goeij ${ }^{2}$, Petra A. Wark ${ }^{3}$, Mirian Brink ${ }^{1}$, Guido \\ M.J.M. Roemen ${ }^{4}$, Marjolein H.F.M. Lentjes', Adriaan P. de Bruïne ${ }^{2}$, R. Alexandra Goldbohm' ${ }^{5}$, Pieter van 't Veer ${ }^{3}$ \\ $\&$ Piet A. van den Brandt ${ }^{1}$ \\ ${ }^{1}$ Department of Epidemiology, Nutrition and Toxicology Research Institute Maastricht (NUTRIM), Maastricht \\ University, 6200 MD Maastricht, The Netherlands; ${ }^{2}$ Department of Pathology, Research Institute Growth and \\ Development (GROW), Maastricht University, 6200 MD Maastricht, The Netherlands; ${ }^{3}$ Division of Human \\ Nutrition, Wageningen University, 6700 EV Wageningen, The Netherlands; ${ }^{4}$ Department of Pathology, Nutrition and \\ Toxicology Research Institute Maastricht (NUTRIM), Maastricht University, 6200 MD Maastricht, The \\ Netherlands; ${ }^{5}$ TNO Nutrition and Food Research, 3700 AJ Zeist, The Netherlands
}

Received 4 October 2004; accepted in revised form 29 April 2005

Key words: adenomatous polyposis coli, colorectal cancer, hMLH1, meat, mutation.

\begin{abstract}
Objective: The aim of this study was to investigate the associations between meat and fish consumption and $A P C$ mutation status and hMLH1 expression in colon and rectal cancer.

Methods: The associations were investigated in the Netherlands Cohort Study, and included 434 colon and 154 rectal cancer patients on whom case-cohort analyses (subcohort $\mathrm{n}=2948$ ) were performed.

Results: Total meat consumption was not associated with the endpoints studied. Meat product (i.e. processed meat) consumption showed a positive association with colon tumours harbouring a truncating $A P C$ mutation, whereas beef consumption was associated with an increased risk of colon tumours without a truncating $A P C$ mutation (incidence rate ratio (RR) highest versus lowest quartile of intake 1.61, 95\% confidence interval (CI) 0.96-2.71, $p$-trend $=0.04$ and $1.58,95 \%$ CI 1.10-2.25, $p$-trend $=0.01$, respectively). Consumption of other meat (horsemeat, lamb, mutton, frankfurters and deep-fried meat rolls) was associated with an increased risk of rectal cancer without a truncating $A P C$ mutation (RR intake versus no intake $1.79,95 \%$ CI 1.10-2.90). No associations were observed for meat consumption and tumours lacking hMLH1 expression.

Conclusions: Our data indicate that several types of meat may contribute differently to the aetiology of colon and rectal cancer, depending on $A P C$ mutation status but not hMLH1 expression of the tumour.
\end{abstract}

\section{Introduction}

Epidemiological studies have led to the current understanding that a significant proportion of colorectal cancer cases may be explained by dietary habits [1]. Although results from epidemiological studies on the risk of diet on colorectal cancer are inconsistent, meat consumption has been associated with an increased risk of colorectal cancer in several studies. According to the

* Address correspondence to: Matty P. Weijenberg, Department of Epidemiology, University Maastricht, P.O. Box 616, 6200 MD Maastricht, The Netherlands. E-mail: mpweijenberg@epid.unimaas.nl
WCRF/AICR report on cancer prevention, evidence from previous studies shows that red meat (fresh meat excluding poultry) probably increases risk of colorectal cancer, and processed meat possibly increases risk [2]. Poultry consumption data are inconsistent and there may be no relationship with colorectal cancer risk [2]. Fish consumption possibly also has no relationship with the risk of colorectal cancer [2]. A recent meta-analysis of 34 case-control and 14 cohort studies, investigating the risk of meat consumption on colorectal cancer concluded that total meat consumption was not significantly associated with colorectal cancer, but high intake of red meat (beef, veal, pork, mutton, and lamb), and in 
particular processed meat, was associated with a moderate but significantly increased risk of colorectal cancer [3].

Most epidemiological studies investigating the consumption of meat as a risk factor have not made a distinction between colon and rectal cancer, or included only colon cancer but not rectal cancer. Previous studies have suggested differences in aetiology between the subsites of the colorectal tract [4]. The colon and rectum arise from different embryonic tissue and serve different functions [5]. The duration of exposure to and the composition of bowel content differ between colon and rectum. Moreover, molecular aspects of tumourigenesis also seem to differ between subsites of the large bowel $[6,7]$.

Most sporadic colorectal cancers are thought to arise through genetic pathways, which involve aberrations in a number of genes, as described by Fearon and Vogelstein (8). Inactivation of the $A P C$ gene is thought to be a key event early in colorectal tumourigenesis. Somatic mutations in the mutation cluster region (MCR) of $A P C$ have been found in $34-70 \%$ of sporadic tumours in colorectal cancer patients, which underscores the importance of $A P C$ gene mutation in sporadic colorectal carcinogenesis [9-17]. The large majority of mutations observed in different studies would lead to a truncated and therefore inactivated APC protein. In our study, using a sensitive mutation detection technique, we found $72 \%$ of patients to have mutations in the $A P C$ gene, but only $37 \%$ of patients had a mutation that would lead to truncation of the APC protein [7]. Moreover, a considerable proportion of patients (29\%) had a colorectal tumour that did not harbour truncating but missense mutations in the $A P C$ gene [7].

In contrast with the majority of sporadic colorectal tumours being chromosomally instable and harbouring mutations in APC, TP53 and K-ras, a smaller subset ( $\sim 10-15 \%$ of tumours) exhibits loss of mismatch repair manifested by microsatellite instability (MSI). Studies have shown that MSI and mutations in $A P C, T P 53$ and $K$-ras occur almost mutually exclusively [18-20], suggesting that these characteristics represent separate pathways. In approximately $90 \%$ of microsatellite instable tumours, absence of human mut-L homologue 1 (hMLH1) expression was observed (21).

Animal fat and the haem iron content of meat as well as meat preparation have been proposed as explanations for meat consumption as a risk factor for colorectal cancer. High temperature cooking of meat proteins generates heterocyclic aromatic amines (HCAs). The most abundant HCA in cooked meat, 2-amino-1-methyl-6-phenylimidazo[4,5-b]pyridine (PhiP), was shown to cause site specific mutations in the $A P C$ gene in rats after induction of colon tumours with PhiP [22]. Nitrosamines and their precursors are compounds that can be formed endogenously [23] but are also found in red and processed meat [24]. Through their alkylating action they can be carcinogenic. $N$-nitroso compounds could induce $\mathrm{G} \rightarrow \mathrm{A}$ transitions that have been observed in codons 12 and 13 of the $K$-ras gene in human colonic tissue [23]. Similarly, meat consumption may be associated with specific mutations in the $A P C$ gene.

To our knowledge, only one study has addressed the issue of studying an association between dietary factors and truncating mutations of the $A P C$ gene in sporadic colon cancer in humans. In this case-control study, meat consumption was associated with colon carcinomas harbouring a truncating mutation in $A P C$ [17]. In another report from that study, an inverse relation between red meat and MSI was found [25].

Here, we investigated the associations between fresh meat, meat products (i.e. processed meat) and fish consumption and the risk of colon and rectal tumours harbouring truncating mutations, missense mutations, and specific types of point mutations in the MCR of the $A P C$ gene in cancer as well as colon tumours with absent hMLH1 expression in a large prospective cohort study in the Netherlands.

\section{Materials and methods}

\section{Study population}

The prospective Netherlands Cohort Study on diet and cancer (NLCS) was initiated in September 1986. The study design has been described in detail elsewhere [26]. Briefly, at baseline a total of 58,279 men and 62,573 women, between the ages of 55 and 69 years, completed a self-administered food frequency and lifestyle questionnaire. The study population originated from 204 municipal population registries throughout the country. For data processing and analysis, the case-cohort approach was used: the cases were enumerated for the entire cohort, while the person years at risk accumulating in the cohort were estimated from a random sample (subcohort). This subcohort of 3,500 men and women was randomly sampled from the cohort after baseline exposure measurement and was followed for migration and vital status by contacting the participants and the municipalities biennially to calculate accumulated person-time in the cohort [27]. About 154 cases with prevalent cancer other than non-melanoma skin cancer were excluded, resulting in a subcohort of 3,346 men and women. During the first 2.3 years of follow-up, 83 subcohort members deceased or were diagnosed with cancer other than non-melanoma skin cancer, leaving 
3263 subcohort members for analysis. No subcohort members were lost to follow-up.

Incident cancer cases are identified by monitoring of the entire cohort for cancer occurrence through annual record linkage to the Netherlands Cancer Registry (NCR), nine regional cancer registries throughout the Netherlands, and to PALGA, a nationwide network and registry of histo- and cytopathology reports [27]. The NCR and PALGA together provide a near $100 \%$ coverage of the municipalities included in the NLCS. The first 2.3 years of follow up were excluded because of possible pre-clinical disease affecting exposure status and because of incomplete nationwide coverage of PALGA in some of the municipalities included in the NLCS. From 1989 until 1994, 929 incident cases with histologically confirmed colorectal cancer were identified within the cohort, of whom 819 could also be linked to a PALGA report of the lesion. The PALGA reports were used to identify and locate tumour tissue from eligible colorectal cancer patients in Dutch pathology laboratories. Colon and rectal cancer were classified according to site as follows, colon: cecum through sigmoid colon (ICD-O codes 153.0, 153.1, 153.2, 153.3, 153.4, 153.5, 153.6, 153.7), rectosigmoid (ICD-O code 154.0), and rectum (ICD-O code 154.1).

\section{Tissue samples}

Tumour material of colorectal cancer patients was collected after approval by the Ethical Review Board of University Maastricht, the NCR and PALGA. Tissue samples from 819 colorectal cancer patients were distributed among 54 pathology laboratories throughout the Netherlands. From $95 \%$ (775/819) of patients tissue samples could be retrieved. Tissue samples from nine patients registered in one pathology laboratory could not be retrieved due to administrative inconsistencies. From 34 patients, tumour tissue blocks were not available in the archive of pathology laboratories. Of 776 tissue samples available, from 20 patients only normal mucosa was available, ten tissue samples were revised as being a benign adenoma instead of a carcinoma by a pathologist (A.d.B.), from six patients, DNA yield was insufficient for molecular analyses, and from three patients the available tissue did not include malignant colorectal cancer tissue. Hence, tumour tissue from 737 colorectal cancer patients was available for $A P C$ mutation analysis and hMLH1 inmmunohistochemistry.

\section{APC mutation analysis}

The majority of somatic mutations in $A P C$ occurs within the MCR. Mutation analysis of this region (codons 1286-1520) was performed on archival adenocarcinoma specimens, using macrodissection to extract tumour DNA, followed by nested polymerase chain reaction (PCR) of the MCR in four overlapping DNA fragments and direct sequencing of purified fragments. This procedure has been described in detail elsewhere [7]. In brief, in a first round of PCR, two overlapping fragments were generated, that served as templates for a second round of PCR to amplify four overlapping biotin-labelled PCR fragments that were subsequently used for direct sequencing. The sequence profile was analysed on ALFexpress DNA Analysis System using ALFwin software (Amersham Biosciences, Roosendaal, The Netherlands). Evaluation of the sequence patterns and data entry was independently performed by two observers. The detection limit was $5 \%$ of mutated DNA. Duplicate experiments revealed good reproducibility $(85 \%)$.

From 72 of the 737 patients, one or more fragments of the MCR could not be amplified and these patients were not included in this study. Since the rectosigmoid can be considered as a clinically applied term rather than an anatomically defined transitional zone between the colon and rectum, patients with a rectosigmoid tumour were excluded from data analysis. Moreover, the group of patients with a rectosigmoid tumour was too small for adequate stratified analysis. After exclusion of the 74 patients with a rectosigmoid tumour, 440 colon and 151 rectal cancer patients remained available.

\section{$h M L H 1$}

Formalin-fixed, paraffin-embedded tissues were sectioned at $4 \mu \mathrm{m}$ and included tumour tissue with normal adjacent mucosa. Endogeneous peroxidase activity 'was blocked with $3 \% \quad \mathrm{H}_{2} \mathrm{O}_{2}$. Slides were submitted to microwave antigen retrieval in $1 \mathrm{mM}$ EDTA buffer $(\mathrm{pH}$ 8.0) and incubated with $10 \%$ normal horse serum for $10 \mathrm{~min}$ at room temperature. Then, sections were incubated overnight at $4{ }^{\circ} \mathrm{C}$ with mouse monoclonal antibodies against hMLH1 protein (clone G168-15, PharMingen, San Diego, CA) at a 1:100 dilution. Antibody binding was detected by incubating the sections at room temperature with the peroxidase-labelled DAKO Envision System (DAKO, Carpinteris, CA) using $\mathrm{DAB}$ as a chromogen. Sections were counterstained with diluted haematoxyline.

Lesions were considered to lack hMLH1 protein expression when unequivocal absence of nuclear staining of the tumour epithelial cells was observed. Nuclear staining of normal epithelial and stromal cells or lymphocytes served as internal positive control. Staining profiles were scored independently by at least two 
observers and in case of discordant results discussed with a pathologist until consensus was reached. hMLH1 expression could be determined in 724 of 737 patients, for whom tumour DNA was available. With the exclusion of 84 patients with a rectosigmoid tumour, 468 colon and 172 rectal cancer cases were available for the analysis.

\section{Exposure assessment}

The dietary section of the questionnaire, a 150-item semi-quantitative food frequency questionnaire, concentrated on habitual intake of food and beverages during the year preceeding the start of the study. Questionnaire data were key-entered twice and processed for all incident cases in the cohort and for all subcohort members in a manner blinded with respect to case/subcohort status in order to minimize observer bias in coding and interpretation of the data.

Subjects whose dietary data were incomplete or inconsistent, were excluded from the analysis, leaving 484 colon cancer patients of whom 13 were also subcohort members and 160 rectal cancer patients of whom one was also a subcohort member, and 3,048 subcohort members. Criteria used for this selection were (a) 60 or more questionnaire items left blank and 35 items that were eaten less than once per month and/or (b) one or more item blocks (groups of items, e.g. beverages) left blank.

The questionnaire contained 14 items on the consumption of meat with the hot meal (mainly fresh meat, including chicken), five items on the consumption of meat products, which are used as sandwich filling, and three items on fish consumption [28]. As for serving sizes, a question was included on the quantity of fresh meat usually purchased (per person, per meal). For meat products, the number of sandwiches filled with a product was asked and a standard serving size per sandwich filling of $15 \mathrm{~g}$ was used. For chicken and fish standard serving sizes were also used. Fresh meat is defined as meat that has not undergone any form of preservation, such as smoking, fermentation, and/or treatment with nitrate and/or nitrite salt ('curing'), which is consumed during the main (hot) meal. Meat products are defined as meat items that have undergone preservation as described above. The questionnaire was validated against a 9-day diet record [29]. The Spearman correlation coefficients for meat, meat products and fish were $0.46,0.54$ and 0.53 , respectively.

Quartiles of intake of fresh meat, beef, pork, minced meat and meat products were computed separately for men and women based on the distribution of intake in subcohort members. For liver and other meat eaten with main meal, categories of intake were a non-user and a user group ( $>0 \mathrm{~g} /$ day). For poultry, categories of intake were classified into a non-user and three user categories $(0-13.2,13.2-22.8$ and $\geq 22.8 \mathrm{~g} /$ day $)$. For fish, categories of intake were a non-user group and three user groups $(0-10,10-20$ and $\geq 20 \mathrm{~g} /$ day $)$.

\section{Statistical analysis}

The data analysis was conducted separately for overall colon and rectal cancer, colon and rectal cancer with or without a truncating $A P C$ mutation, described here as $A P C^{+}$and $A P C^{-}$tumours, and colon cancer lacking hMLH1 expression. In addition, in colon and rectal cancer without a truncating $A P C$ mutation, separate analyses were conducted for tumours harbouring a missense $A P C$ mutation and tumours that did not have such a mutation. Finally, tumours with a specific $\mathrm{C}: \mathrm{G} \rightarrow \mathrm{T}: \mathrm{A}$ or $\mathrm{G}: \mathrm{C} \rightarrow \mathrm{T}: \mathrm{A}$ point mutation, irrespective of their putative effect were analysed. Truncating $A P C$ mutations lead to introduction of a stop codon and would result in a truncated and therefore inactive $A P C$ protein. Missense mutations lead to alteration of a single amino acid at the protein level. In the data analysis, associations with missense mutations in $A P C$ were studied in patients with at least one missense mutation, but without a truncating mutation.

Mean values of the intake of fresh meat, beef, pork, minced meat, liver, other meat, poultry, meat products, fish (all g/day), and possible confounding variables including age at baseline (years), intake of vegetable (g/day), fruit (g/day), alcohol (g/day), fat (g/day), dietary fibre $(\mathrm{g} /$ day), calcium $(\mathrm{mg} /$ day), energy $(\mathrm{kJ} /$ day), and body mass index (BMI) $\left(\mathrm{kg} / \mathrm{m}^{2}\right)$, as well as distributions of the variables sex, family history of colorectal cancer (yes/ no), smoking status (never/ex/current smoker) and physical activity in leisure time $(<30,30-60,60-90$, $>90 \mathrm{~min} /$ day) were evaluated for subcohort members, colon and rectal cancer patients with or without a truncating $A P C$ mutation and colon cancer patients lacking hMLH1 expression. Differences in distribution of the continuous variables between patients with or without truncating nonsense or frameshift mutations in the MCR of the $A P C$ gene were tested with the Student's $T$-test or the Mann-Whitney- $U$-test if the variables were not normally distributed. The distributions of the categorical variables between patients with and without truncating $A P C$ mutations were compared with the $\chi^{2}$ test.

Incidence rate ratios (RR) and corresponding 95\% confidence interval (CI) for colon and rectal cancer patients according to quartiles or categories of intake of fresh meat, meat products and fish intake and one standard deviation increment of intake were estimated using Cox proportional hazards regression models. In 
addition, associations were estimated for specific molecular endpoints of the tumours.

Standard errors were estimated using the robust Huber-White sandwich estimator to account for additional variance introduced by sampling from the cohort [30]. The proportional hazards assumption was tested using the scaled Schoenfeld residuals [31]. Tests for dose response trends over the different quartiles and categories of meat and fish intake were estimated by fitting the ordinal exposure variables as continuous variables using the Wald test.

Age at baseline, sex, intake of vegetables, fruit, alcohol, fat, dietary fibre, calcium, BMI, smoking status, family history of colorectal cancer, energy intake, and physical activity in leisure time were considered as potential confounders. Those variables that were found to statistically significantly $(p<0.05)$ contribute to the multivariate model for colon and/or rectal cancer (age at baseline, sex, BMI, family history of colorectal cancer, and smoking status), as well as energy intake, were included as covariates in the multivariate analyses. None of the above-mentioned variables influenced the risk estimates by more than ten percent.

\section{Results}

The flow diagram of patients and subcohort members available for the analyses, is depicted in Figure 1. About 434 colon and 154 rectal cancer patients for whom tumour material was available were included in the analysis of meat and fish consumption as a risk factor for colon and rectal cancer. Of the colon tumours, 220 were localised in the proximal colon, 204 in the distal colon and from 10 localisation was unspecified. With regard to Dukes stage, 77 colon tumours were graded Dukes A, 154 Dukes B, 112 Dukes C, 59 Dukes D, and 32 were unspecified, 59 rectal tumours were graded Dukes A, 32 Dukes B, 40 Dukes C, and 11 Dukes D, and 12 were unspecified.

Of the 401 colon and 130 rectal cancer patients, for whom $A P C$ mutation analysis was complete, $35 \%(188 /$ $535)$ had one or more mutations in the MCR of the $A P C$ gene that would lead to introduction of a stop codon and hence to a truncated and therefore inactive APC protein. In addition to these nonsense and frameshift mutations, a large number of silent and missense mutations were observed. When considering all mutations, regardless of their putative effect, $81 \%(431 / 535)$ of patients harboured at least one mutation in the $A P C$ gene. Multiple mutations in the $A P C$ gene were observed in tumours from $44 \%(236 / 535)$ of patients. These figures are similar to the results that were ob- tained for the all patients, including rectosigmoid cancer patients that were analysed for the occurrence of $A P C$ mutations [7].

In 428 colon and 148 rectal cancer patients hMLH1 expression was determined. Of the colon tumours 54 were hMLH1 deficient, 49 of which were located in the proximal colon. Two rectal tumours lacked hMLH1 expression. Therefore, associations between meat and fish consumption and hMLH1 deficiency were investigated for colon cancer only.

The baseline characteristics of the patients and subcohort members are presented in Table 1. Colon and rectal cancer patients were older, more often men, more often had a family history of colorectal cancer and were more often ex-smokers as compared to the subcohort (data not shown). Rectal cancer patients had a higher daily intake of alcohol than subcohort members. Colon cancer patients lacking hMLH1 expression had a lower intake of fibre than those expressing hMLH1 $(25.2 \pm 7.1$ versus $27.5 \pm 8.1 \mathrm{~g} /$ day, $p=0.05)$. Colon cancer patients with a tumour harbouring a truncating $A P C$ mutation $\left(A P C^{+}\right)$, had a higher intake of liver $(2.6 \pm 4.5$ versus $1.5 \pm 3.7 \mathrm{~g} / \mathrm{day}, p=0.01)$ and meat products $\quad(17.3 \pm 20.0$ versus $12.7 \pm 13.2 \mathrm{~g} /$ day, $p=0.01)$ than colon cancer patients without a truncating $A P C$ mutation $\left(A P C^{-}\right)$. The energy intake of colon cancer patients with an $A P C^{+}$tumour was also higher than patients with an $A P C^{-}$tumour $(8335 \pm 2306$ versus $7840 \pm 1897 \mathrm{~kJ}, p=0.03)$. No significant differences between rectal cancer patients with or without a truncating $A P C$ mutation were observed.

Associations between the consumption of several types of meat, meat products and fish with the risk of colon or rectal cancer are presented in Table 2. RR and 95\% CI for colon and rectal cancer were adjusted for age and sex only as well as for age, sex, smoking, BMI, energy intake and family history of colorectal cancer. The age and sex adjusted RR and the multivariate RR were similar. A high consumption of beef seemed associated with an increased risk of colon cancer (RR for highest versus lowest quartile of intake $1.29,95 \% \mathrm{CI}$ 0.96-1.73, p-trend 0.06). However, pork consumption seemed associated with a decreased risk of both colon cancer (RR for highest versus lowest quartile of intake $0.77,95 \%$ CI $0.57-1.04$, $p$-trend 0.07 ) and rectal cancer (RR for highest versus lowest quartile of intake 0.70 , 95\% CI 0.44-1.13, p-trend 0.09). Total fresh meat consumption was not associated with the overall risk of colon or rectal cancer.

Associations of several types of meat, meat products, and fish with tumours without truncating $A P C$ mutations $\left(A P C^{-}\right)$and tumours with a truncating $A P C$ 
mutation $\left(\mathrm{APC}^{+}\right)$of colon and rectum are shown in Table 3. Total fresh meat consumption was not associated with risk of $A P C^{+}$or $A P C^{-}$colon tumours. A high consumption of beef was associated with an increased risk of colon tumours without an $A P C$ nonsense or frameshift mutation (RR for highest versus lowest quartile of intake $1.58,95 \%$ CI 1.10-2.25, p-trend 0.01). Because the $A P C^{-}$colon tumours consisted of tumours that harboured a missense mutation $(\mathrm{n}=130)$ and tumours that did not harbour such a mutation $(\mathrm{n}=144)$, these group were analysed separately. The risk estimates for both groups were similar (RR for highest versus lowest quartile of intake $1.64,95 \%$ CI $0.99-2.71, p$-trend 0.03 and $1.52,95 \%$ CI $0.95-2.45, p$-trend 0.09 , respectively). The risk of an $A P C^{+}$colon cancer was increased by high meat product consumption (RR for highest versus lowest quartile of intake 1.61, 95\% CI 0.96-2.71, $p$-trend $=0.04)$.

For rectal cancer, consumption of total fresh meat and beef seemed to be associated with a decreased risk of $\mathrm{APC}^{+}$tumours (RR for highest versus lowest quartile of intake 0.48 and $0.53,95 \%$ CI $0.20-1.12$ and $0.24-$ 1.19 , respectively, $p$-trend 0.05 for both). Consumption of other meat showed a statistically significant increased risk of $A P C^{-}$rectal tumours (RR for intake versus no intake $1.79,95 \%$ CI 1.10-2.90). When incidence risk ratios were calculated for tumours that harboured a missense mutation $(\mathrm{n}=32)$ and tumours that did not harbour such a mutation $(n=41)$, these were similar, but did not reach statistical significance (RR for intake versus no intake $1.99,95 \%$ CI $0.95-4.16$ and $1.64,95 \%$ CI 0.88-3.08, respectively).

When considering colon and rectal tumours that harboured a $\mathrm{C} \rightarrow \mathrm{T}$ or $\mathrm{G} \rightarrow \mathrm{A}$ mutation, irrespective of its putative effect, no clear associations were observed for any of the meat variables and 214 colon cancer patients with such a mutation (data not shown). Other meat consumption was associated with an increased risk of rectal cancer with a $\mathrm{C} \rightarrow \mathrm{T}$ or $\mathrm{G} \rightarrow \mathrm{A}$ mutation $(\mathrm{n}=70)(\mathrm{RR}$ for intake versus no intake $1.75,95 \% \mathrm{CI}$ 1.06-2.89), but is similar to the risk observed for rectal cancer without a truncating $A P C$ mutation.

No associations were observed for any of the meat variables with colon tumours lacking hMLH1 expression (Table 4).

\section{Discussion}

Although colorectal cancer has often been studied as a single endpoint in epidemiologic studies, several differences between colon and rectal cancer have been described, such as differences in aetiology of tumour formation [4, 5]. It has also been suggested that the molecular profile of tumours varies along the colorectal tract. We previously found asymmetry with respect to $A P C$ mutation status, more truncating $A P C$ mutations were observed in rectal than in colon cancer [7]. In the present study, we evaluated the associations between meat, meat products, and fish intake and the risk of colon and rectal cancer with and without mutations in the MCR of the APC gene and the expression of the mismatch repair enzyme hMLH1.

For colon cancer, 401 patients could be included in this study, which gave rise to reasonable power to perform sub-group analyses for $A P C$ mutation status of the tumours. The limited number of 130 rectal cancer patients included in this study provides limited power, especially when estimating risk of rectal cancer with or without an APC mutation. It should be noted that patients with tumours in the rectosigmoid were excluded from the analyses, to make a clear distinction between colon and rectum tumours. Moreover, because we have run several analyses to estimate risk ratios for different subsets of colon and rectal tumours based on $A P C$ mutation status, the associations observed in this study need to be treated with some caution and would need confirmation in a larger study. The loss of patients initially recognised within the cohort, due to irretrievable tumour material, incomplete analysis of the $A P C$ gene and incompleteness of the food frequency questionnaire, may have influenced the observed results. However, risk estimates for meat and fish consumption for the group under study here, were similar to the results obtained for all 819 patients originally recognised within the cohort (data not shown).

Previous studies have not always taken into account possible differences between sub-localizations along the colorectal tract. Risk factors for colon and rectal cancer seem to differ, although in a recent study by Wei et al. the risks associated with servings of beef, pork or lamb or processed meats were not found to differ for colon and rectum [4]. We found some differences between colon and rectal cancer. The risk of colon cancer seemed to be increased with high intake of beef, whereas for rectal cancer total fresh meat consumption was found to be protective.

We observed no significant association between meat or fish consumption and overall risk of colon cancer, although there seemed to be a positive association with beef consumption. The associations seemed stronger for rectal than for colon cancer. A recent meta-analysis including 34 case-control and 14 cohort studies also found no risk of colorectal cancer associated with total meat intake, but a moderately increased risk associated 


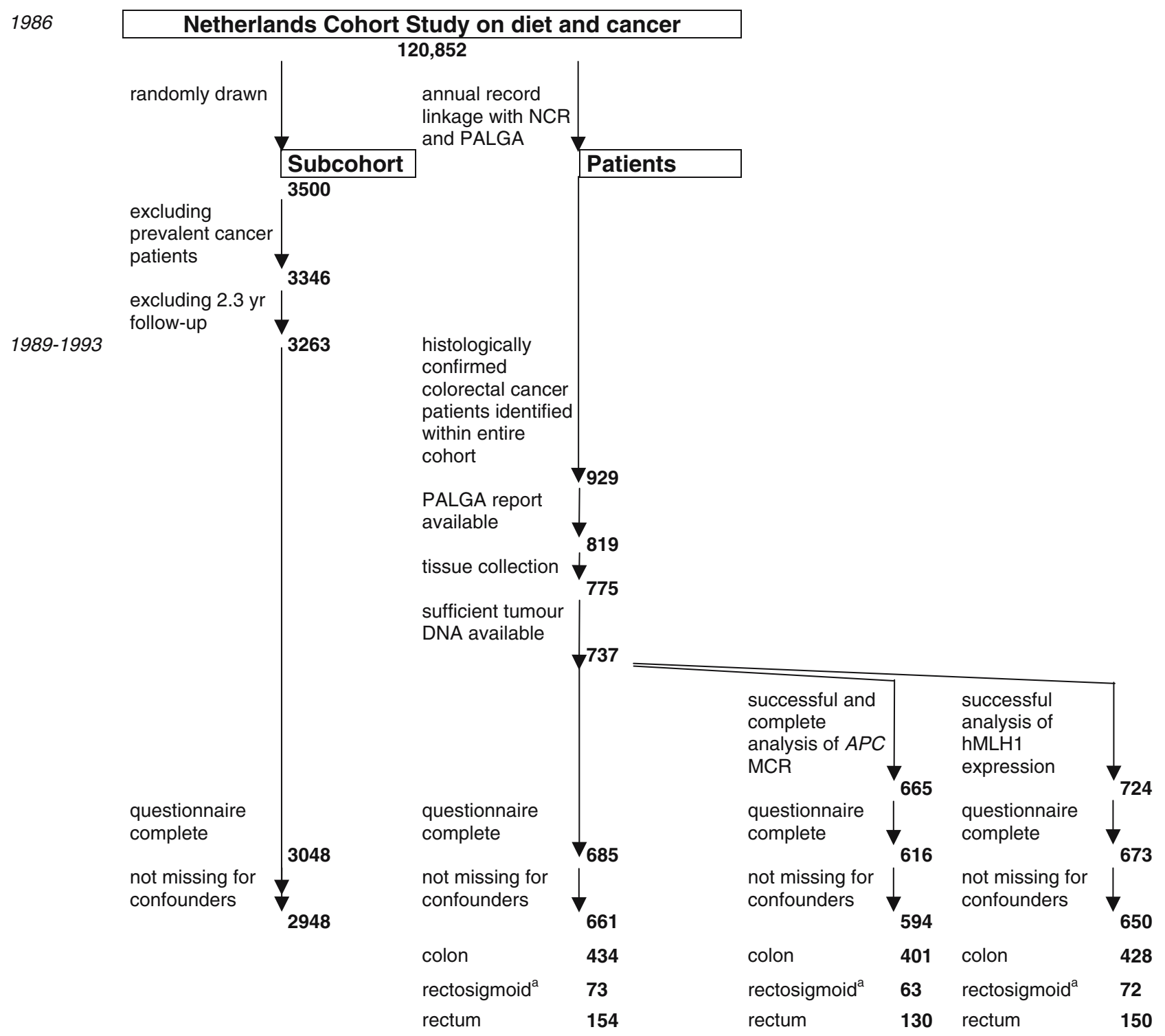

Fig. 1. Flow diagram of subcohort members and colorectal cancer patients on whom the analyses are based. ${ }^{a}$ Patients with rectosigmoid tumours were not included in the analysis.

with red meat and particularly processed meat consumption [3]. In a recent systematic review of meat consumption and colorectal cancer risk in prospective cohort studies, a positive association was found between all meat, red meat and in particular processed meat consumption and colorectal cancer risk [32]. The positive association between all meat consumption and colorectal cancer risk in the latter study may be due to inclusion of processed meat in the analysis of the 'all meat' variable and differs from the 'total fresh meat' variable used in our study in that respect, and residual confounding may be present in the systemic review.
Whereas we found beef consumption to be positively associated with risk of colon cancer, pork consumption was inversely associated with colon cancer risk. Confounding of the associations of consumption of beef or pork by pork or beef, respectively, seems unlikely, as mutually adjusting the analysis for beef and pork consumption did not influence risk estimates. An explanation of the observed difference in risk may lie in the differences in preparation and haem iron content of beef and pork.

The differences between colon and rectal cancer are more complex as these also involve a variety of genetic aberrations. MSI is most frequently observed in the 
Table 2. Adjusted ${ }^{\mathrm{a}}$ incidence rate ratios $(\mathrm{RR})$ and $95 \%$ confidence intervals $(\mathrm{CI})$ for colon $(\mathrm{n}=434)$ and rectal $(\mathrm{n}=154)$ cancer patients according to quartiles and categories of intake of fresh meat, types of fresh meat, meat products, and fish

\begin{tabular}{|c|c|c|c|c|c|c|c|c|c|}
\hline & \multicolumn{2}{|c|}{$\begin{array}{l}\text { Median intake } \\
(\mathrm{g} / \text { day })\end{array}$} & \multirow[t]{2}{*}{ Person years } & \multicolumn{3}{|c|}{ Colon cancer } & \multicolumn{3}{|c|}{ Rectal cancer } \\
\hline & Men & $\overline{\text { Women }}$ & & $N$ cases & $\mathrm{RR}$ & $95 \% \mathrm{CI}$ & $N$ cases & $\mathrm{RR}$ & $95 \% \mathrm{CI}$ \\
\hline \multicolumn{10}{|c|}{ Total fresh meat } \\
\hline 1 & 61 & 50.7 & 3533 & 103 & 1.00 & & 40 & 1.00 & \\
\hline 2 & 91 & 80.3 & 3606 & 109 & 1.04 & $0.78-1.40$ & 45 & 1.11 & $0.71-1.72$ \\
\hline 3 & 110.7 & 103.4 & 3561 & 121 & 1.11 & $0.83-1.49$ & 39 & 0.93 & $0.59-1.47$ \\
\hline 4 & 150.8 & 139.2 & 3572 & 101 & 0.96 & $0.71-1.31$ & 30 & 0.72 & $0.44-1.19$ \\
\hline$p$-trend & & & & & 0.92 & & & 0.14 & \\
\hline $1 \mathrm{SD}$ & & & & & 0.96 & $0.87-1.06$ & & 0.89 & $0.76-1.05$ \\
\hline \multicolumn{10}{|l|}{ Beef } \\
\hline 1 & 4.1 & 3 & 3561 & 94 & 1.00 & & 37 & 1.00 & \\
\hline 2 & 16.1 & 14 & 3640 & 95 & 0.98 & $0.72-1.33$ & 48 & 1.24 & $0.80-1.96$ \\
\hline 3 & 30 & 25.5 & 3557 & 111 & 1.09 & $0.81-1.47$ & 31 & 0.79 & $0.48-1.31$ \\
\hline 4 & 51.4 & 46.9 & 3514 & 134 & 1.29 & $0.96-1.73$ & 38 & 0.95 & $0.59-1.54$ \\
\hline$p$-trend & & & & & 0.06 & & & 0.42 & \\
\hline $1 \mathrm{SD}$ & & & & & 1.06 & $0.97-1.17$ & & 0.94 & $0.78-1.14$ \\
\hline \multicolumn{10}{|l|}{ Pork } \\
\hline 1 & 7.9 & 5 & 3497 & 118 & 1.00 & & 43 & 1.00 & \\
\hline 2 & 28 & 22.5 & 3564 & 116 & 0.98 & $0.74-1.30$ & 44 & 1.01 & $0.65-1.56$ \\
\hline 3 & 44.3 & 40.1 & 3569 & 108 & 0.90 & $0.67-1.20$ & 36 & 0.81 & $0.51-1.28$ \\
\hline 4 & 76 & 66.2 & 3642 & 92 & 0.77 & $0.57-1.04$ & 31 & 0.70 & $0.44-1.13$ \\
\hline$p$-trend & & & & & 0.07 & & & 0.09 & \\
\hline $1 \mathrm{SD}$ & & & & & 0.93 & $0.84-1.04$ & & 0.87 & $0.73-1.03$ \\
\hline \multicolumn{10}{|c|}{ Minced meat } \\
\hline 1 & 3.2 & 0 & 3525 & 100 & 1.00 & & 33 & 1.00 & \\
\hline 2 & 11.5 & 9.6 & 3605 & 116 & 1.11 & $0.83-1.49$ & 36 & 1.06 & $0.65-1.72$ \\
\hline 3 & 21 & 18.1 & 3605 & 125 & 1.26 & $0.94-1.69$ & 52 & 1.60 & $1.01-2.52$ \\
\hline 4 & 37.8 & 32.9 & 3536 & 93 & 0.93 & $0.68-1.27$ & 33 & 1.01 & $0.61-1.66$ \\
\hline$p$-trend & & & & & 0.88 & & & 0.50 & \\
\hline $1 \mathrm{SD}$ & & & & & 0.95 & $0.88-1.04$ & & 1.06 & $0.93-1.21$ \\
\hline \multicolumn{10}{|l|}{ Liver } \\
\hline 1 & 0 & 0 & 9247 & 282 & 1.00 & & 96 & 1.00 & \\
\hline 2 & 4.1 & 3.7 & 5025 & 152 & 1.04 & $0.84-1.29$ & 58 & 1.11 & $0.79-1.57$ \\
\hline \multicolumn{10}{|c|}{ Other meat } \\
\hline 1 & 0 & 0 & 10098 & 302 & 1.00 & & 100 & 1.00 & \\
\hline 2 & 6.6 & 7 & 4173 & 132 & 1.16 & $0.92-1.45$ & 54 & 1.34 & $0.94-1.90$ \\
\hline \multicolumn{10}{|l|}{ Poultry } \\
\hline 1 & 0 & 0 & 3297 & 115 & 1.00 & & 33 & 1.00 & \\
\hline 2 & 5.3 & 5.3 & 3464 & 100 & 0.85 & $0.63-1.14$ & 43 & 1.27 & $0.79-2.03$ \\
\hline 3 & 13.2 & 13.2 & 3534 & 97 & 0.81 & $0.60-1.08$ & 33 & 0.94 & $0.57-1.54$ \\
\hline 4 & 22.8 & 22.8 & 3978 & 122 & 0.87 & $0.66-1.15$ & 45 & 1.12 & $0.70-1.79$ \\
\hline$p$-trend & & & & & 0.33 & & & 0.96 & \\
\hline $1 \mathrm{SD}$ & & & & & 0.95 & $0.87-1.05$ & & 0.98 & $0.83-1.14$ \\
\hline \multicolumn{10}{|c|}{ Meat products } \\
\hline 1 & 1 & 0 & 3444 & 105 & 1.00 & & 42 & 1.00 & \\
\hline 2 & 7.4 & 4.3 & 3541 & 92 & 0.89 & $0.65-1.21$ & 29 & 0.68 & $0.41-1.11$ \\
\hline 3 & 15.8 & 10.5 & 3682 & 117 & 1.05 & $0.78-1.42$ & 38 & 0.84 & $0.53-1.34$ \\
\hline 4 & 33.3 & 22.4 & 3606 & 120 & 1.17 & $0.86-1.59$ & 45 & 1.04 & $0.64-1.68$ \\
\hline$p$-trend & & & & & 0.20 & & & 0.71 & \\
\hline $1 \mathrm{SD}$ & & & & & 1.05 & $0.94-1.17$ & & 0.97 & $0.83-1.14$ \\
\hline \multicolumn{10}{|l|}{ Fish } \\
\hline 1 & 0 & 0 & 4089 & 121 & 1.00 & & 44 & 1.00 & \\
\hline 2 & 4.6 & 4.6 & 3140 & 117 & 1.30 & $0.97-1.72$ & 31 & 0.89 & $0.55-1.43$ \\
\hline 3 & 14.8 & 15.5 & 4318 & 109 & 0.82 & $0.62-1.09$ & 48 & 0.97 & $0.63-1.48$ \\
\hline 4 & 30.5 & 28.2 & 2725 & 87 & 1.03 & $0.76-1.40$ & 31 & 0.94 & $0.59-1.52$ \\
\hline$p$-trend & & & & & 0.40 & & & 0.89 & \\
\hline $1 \mathrm{SD}$ & & & & & 0.93 & $0.84-1.04$ & & 0.93 & $0.81-1.07$ \\
\hline
\end{tabular}

\footnotetext{
${ }^{a}$ Adjusted for age, sex, family history of colorectal cancer, smoking status, BMI, and energy intake.
} 
Table 3. Adjusted incidence rate ratios (RR) and $95 \%$ confidence interval (CI) for colon and rectal cancer patients with and without truncating $A P C$ gene mutations according to quartiles and categories intake of fresh meat, types of fresh meat, meat products, and fish

\begin{tabular}{|c|c|c|c|c|c|c|c|c|c|c|c|c|c|c|c|}
\hline & \multicolumn{2}{|c|}{$\begin{array}{l}\text { Median intake } \\
(\mathrm{g} / \text { day })\end{array}$} & \multirow[t]{3}{*}{ Person years } & \multicolumn{6}{|c|}{ Colon cancer } & \multicolumn{6}{|c|}{ Rectal cancer } \\
\hline & \multirow[t]{2}{*}{ Men } & \multirow[t]{2}{*}{ Women } & & \multicolumn{3}{|l|}{ APC- } & \multicolumn{3}{|l|}{$\mathrm{APC}+$} & \multicolumn{3}{|l|}{ APC- } & \multicolumn{3}{|l|}{$\mathrm{APC}+$} \\
\hline & & & & $N$ cases & $\mathrm{RR}$ & $95 \% \mathrm{CI}$ & $N$ cases & $\mathrm{RR}$ & $95 \% \mathrm{CI}$ & $N$ cases & $\mathrm{RR}$ & $95 \% \mathrm{CI}$ & $N$ cases & $\mathrm{RR}$ & $95 \% \mathrm{CI}$ \\
\hline \multicolumn{16}{|c|}{ Total fresh meat } \\
\hline 1 & 61 & 50.7 & 3533 & 61 & 1.00 & & 33 & 1.00 & & 18 & 1.00 & & 16 & 1.00 & \\
\hline 2 & 91 & 80.3 & 3606 & 71 & 1.17 & $0.81-1.68$ & 32 & 0.93 & $0.56-1.53$ & 22 & 1.18 & $0.63-2.23$ & 19 & 1.16 & $0.59-2.30$ \\
\hline 3 & 110.7 & 103.4 & 3561 & 75 & 1.20 & $0.84-1.73$ & 33 & 0.89 & $0.54-1.47$ & 18 & 0.93 & $0.48-1.81$ & 14 & 0.84 & $0.41-1.73$ \\
\hline 4 & 150.8 & 139.2 & 3572 & 67 & 1.14 & $0.78-1.66$ & 29 & 0.76 & $0.45-1.28$ & 15 & 0.76 & $0.38-1.54$ & 8 & 0.48 & $0.20-1.12$ \\
\hline$p$-trend & & & & & 0.48 & & & 0.30 & & & 0.33 & & & 0.05 & \\
\hline $1 \mathrm{SD}$ & & & & & 1.01 & $0.90-1.14$ & & 0.91 & $0.76-1.08$ & & 0.85 & $0.70-1.05$ & & 0.80 & $0.61-1.04$ \\
\hline \multicolumn{16}{|l|}{ Beef } \\
\hline 1 & 4.1 & 3 & 3561 & 56 & 1.00 & & 32 & 1.00 & & 15 & 1.00 & & 17 & 1.00 & \\
\hline 2 & 16.1 & 14 & 3640 & 56 & 0.99 & $0.67-1.46$ & 27 & 0.79 & $0.47-1.33$ & 21 & 1.34 & $0.67-2.68$ & 19 & 1.06 & $0.54-2.07$ \\
\hline 3 & 30 & 25.5 & 3557 & 66 & 1.10 & $0.76-1.61$ & 37 & 1.05 & $0.64-1.71$ & 15 & 0.95 & $0.45-2.00$ & 11 & 0.61 & $0.28-1.33$ \\
\hline 4 & 51.4 & 46.9 & 3514 & 96 & 1.58 & $1.10-2.25$ & 31 & 0.84 & $0.50-1.42$ & 22 & 1.37 & $0.69-2.74$ & 10 & 0.53 & $0.24-1.19$ \\
\hline$p$-trend & & & & & 0.01 & & & 0.79 & & & 0.58 & & & 0.05 & \\
\hline $1 \mathrm{SD}$ & & & & & 1.13 & $1.01-1.25$ & & 0.95 & $0.79-1.13$ & & 1.00 & $0.80-1.24$ & & 0.79 & $0.53-1.16$ \\
\hline Pork & & & & & & & & & & & & & & & \\
\hline 1 & 7.9 & 5 & 3497 & 75 & 1.00 & & 34 & 1.00 & & 20 & 1.00 & & 16 & 1.00 & \\
\hline 2 & 28 & 22.5 & 3564 & 78 & 1.05 & $0.75-1.47$ & 33 & 0.94 & $0.57-1.54$ & 21 & 1.02 & $0.55-1.89$ & 17 & 1.05 & $0.53-2.10$ \\
\hline 3 & 44.3 & 40.1 & 3569 & 60 & 0.81 & $0.56-1.16$ & 34 & 0.93 & $0.57-1.54$ & 20 & 0.94 & $0.50-1.78$ & 11 & 0.67 & $0.31-1.46$ \\
\hline 4 & 76 & 66.2 & 3642 & 61 & 0.84 & $0.58-1.20$ & 26 & 0.69 & $0.40-1.19$ & 12 & 0.56 & $0.27-1.16$ & 13 & 0.80 & $0.39-1.67$ \\
\hline$p$-trend & & & & & 0.17 & & & 0.20 & & & 0.11 & & & 0.36 & \\
\hline $1 \mathrm{SD}$ & & & & & 0.95 & $0.83-1.08$ & & 0.93 & $0.77-1.14$ & & 0.73 & $0.57-0.93$ & & 0.99 & $0.74-1.31$ \\
\hline Minced $\mathrm{m}$ & & & & & & & & & & & & & & & \\
\hline 1 & 3.2 & 0 & 3525 & 58 & 1.00 & & 33 & 1.00 & & 16 & 1.00 & & 12 & 1.00 & \\
\hline 2 & 11.5 & 9.6 & 3605 & 70 & 1.17 & $0.81-1.70$ & 36 & 1.01 & $0.62-1.65$ & 14 & 0.83 & $0.40-1.72$ & 16 & 1.30 & $0.61-2.78$ \\
\hline 3 & 21 & 18.1 & 3605 & 81 & 1.45 & $1.01-2.09$ & 37 & 1.05 & $0.65-1.72$ & 32 & 1.97 & $1.06-3.64$ & 14 & 1.19 & $0.54-2.61$ \\
\hline 4 & 37.8 & 32.9 & 3536 & 65 & 1.15 & $0.78-1.68$ & 21 & 0.59 & $0.33-1.03$ & 11 & 0.67 & $0.31-1.44$ & 15 & 1.27 & $0.58-2.79$ \\
\hline$p$-trend & & & & & 0.29 & & & 0.08 & & & 0.92 & & & 0.64 & \\
\hline $1 \mathrm{SD}$ & & & & & 1.02 & $0.93-1.12$ & & 0.83 & $0.70-0.98$ & & 1.02 & $0.85-1.22$ & & 0.99 & $0.81-1.22$ \\
\hline Liver & & & & & & & & & & & & & & & \\
\hline 1 & 0 & 0 & 9247 & 187 & 1.00 & & 73 & 1.00 & & 46 & 1.00 & & 34 & 1.00 & \\
\hline 2 & 4.1 & 3.7 & 5025 & 87 & 0.92 & $0.70-1.21$ & 54 & 1.34 & $0.95-2.00$ & 27 & 1.07 & $0.65-1.76$ & 23 & 1.23 & $0.72-2.12$ \\
\hline Other mea & & & & & & & & & & & & & & & \\
\hline 1 & 0 & 0 & 10098 & 188 & 1.00 & & 88 & 1.00 & & 42 & 1.00 & & 37 & 1.00 & \\
\hline 2 & 6.6 & 7 & 4173 & 86 & 1.25 & $0.95-1.64$ & 39 & 1.11 & $0.74-1.65$ & 31 & 1.79 & $1.10-2.90$ & 20 & 1.34 & $0.76-2.36$ \\
\hline Poultry & & & & & & & & & & & & & & & \\
\hline 1 & 0 & 0 & 3297 & 72 & 1.00 & & 34 & 1.00 & & 15 & 1.00 & & 12 & 1.00 & \\
\hline 2 & 5.3 & 5.3 & 3464 & 71 & 0.97 & $0.68-1.37$ & 23 & 0.65 & $0.38-1.12$ & 18 & 1.15 & 2.32 & 17 & 1.39 & $0.65-2.96$ \\
\hline 3 & 13.2 & 13.2 & 3534 & 59 & 0.79 & $0.55-1.14$ & 30 & 0.82 & $0.50-1.35$ & 16 & 0.98 & $0.48-2.02$ & 15 & 1.17 & $0.54-2.54$ \\
\hline 4 & 22.8 & 22.8 & 3978 & 72 & 0.83 & $0.58-1.18$ & 40 & 0.94 & $0.59-1.50$ & 24 & 1.29 & $0.66-2.50$ & 13 & 0.90 & $0.40-2.01$ \\
\hline$p$-trend & & & & & 0.19 & & & 0.95 & & & 0.55 & & & 0.64 & \\
\hline $1 \mathrm{SD}$ & & & & & 0.90 & $0.78-1.04$ & & 1.06 & $0.89-1.25$ & & 1.08 & $0.88-1.32$ & & 0.79 & $0.59-1.05$ \\
\hline Meat prod & ducts & & & & & & & & & & & & & & \\
\hline 1 & 1 & 0 & 3444 & 71 & 1.00 & & 26 & 1.00 & & 20 & 1.00 & & 15 & 1.00 & \\
\hline 2 & 7.4 & 4.3 & 3541 & 62 & 0.90 & $0.62-1.30$ & 23 & 0.87 & $0.49-1.56$ & 12 & 0.57 & $0.27-1.19$ & 12 & 0.79 & $0.36-1.74$ \\
\hline 3 & 15.8 & 10.5 & 3682 & 71 & 0.97 & $0.68-1.39$ & 33 & 1.15 & $0.67-1.97$ & 19 & 0.85 & $0.44-1.65$ & 14 & 0.89 & $0.41-1.92$ \\
\hline 4 & 33.3 & 22.4 & 3606 & 70 & 1.07 & $0.73-1.56$ & 45 & 1.61 & $0.96-2.71$ & 22 & 1.02 & $0.52-1.99$ & 16 & 1.03 & $0.47-2.27$ \\
\hline$p$-trend & & & & & 0.66 & & & 0.04 & & & 0.73 & & & 0.88 & \\
\hline $1 \mathrm{SD}$ & & & & & 0.99 & $0.68-1.14$ & & 1.20 & $1.01-1.42$ & & 0.97 & $0.78-1.20$ & & 0.96 & $0.76-1.22$ \\
\hline Fish & & & & & & & & & & & & & & & \\
\hline 1 & 0 & 0 & 4089 & 73 & 1.00 & & 37 & 1.00 & & 19 & 1.00 & & 19 & 1.00 & \\
\hline 2 & 4.6 & 4.6 & 3140 & 77 & 1.42 & $1.00-2.01$ & 32 & 1.15 & $0.70-1.90$ & 14 & 0.91 & $0.45-1.86$ & 11 & 0.73 & $0.34-1.56$ \\
\hline 3 & 14.8 & 15.5 & 4318 & 68 & 0.86 & $0.60-1.22$ & 33 & 0.80 & $0.49-1.32$ & 24 & 1.10 & $0.60-2.03$ & 19 & 0.90 & $0.47-1.73$ \\
\hline 4 & 30.5 & 28.2 & 2725 & 56 & 1.13 & $0.78-1.64$ & 25 & 0.92 & $0.54-1.56$ & 16 & 1.10 & $0.56-2.18$ & 8 & 0.56 & $0.24-1.30$ \\
\hline$p$-trend & & & & & 0.77 & & & 0.44 & & & 0.67 & & & 0.27 & \\
\hline $1 \mathrm{SD}$ & & & & & 0.95 & $0.83-1.08$ & & 0.92 & $0.76-1.12$ & & 0.99 & $0.82-1.18$ & & 0.83 & $0.63-1.07$ \\
\hline
\end{tabular}

${ }^{\text {a }}$ Adjusted for age, sex, family history of colorectal cancer, smoking status, BMI, and energy intake. 
proximal colon, whereas mutations in the $A P C$ and $K$-ras gene occur more frequently in the distal colon and rectum (18-20). When taking into account the $A P C$ gene mutation status, we found specific associations between meat variables and colon and rectal cancer. Differences in associations between colon and rectal cancer and meat consumption may be explained by $A P C$ gene mutation status rather than by differences in exposure of the colon or rectum to meat. Consumption of meat products, i.e. processed meat, significantly increased risk of $\mathrm{APC}^{+}$colon tumours. Beef intake was associated with an increased risk of $A P C^{-}$colon cancer. Total meat intake and in particular beef intake appears to be associated with a decreased risk of $A P C^{+}$rectal cancer. No associations for poultry or fish were observed. In a case-control study of dietary intake and risk of colon cancer with or without truncating $A P C$ mutations, moderate positive associations for colon tumours that harbour a truncating $A P C$ mutation were found with red meat and fish consumption [17]. The discrepancy between the results from the case-control study and from our study may be attributable to a different exposure assessment of meat consumption in the case control study (e.g., red meat); alternatively, information bias may have played a role while the limited number of subjects in the case-control study (184 cases, 259 controls) may have resulted in chance findings.

$N$-nitroso compounds found in processed meats could induce $\mathrm{G} \rightarrow \mathrm{A}$ transitions that have been observed in codons 12 and 13 of the K-ras gene in human colonic tissue [23]. In one of our previous studies, meat product consumption was found to be associated with $\mathrm{G} \rightarrow \mathrm{A}$ transitions in the $K$-ras gene, but only in rectal cancer [34]. We found a positive association for meat product consumption with $\mathrm{APC}^{+}$colon tumours. Since a $\mathrm{G} \rightarrow$ A transition may occur on the non-coding strand, this would give rise to detection of a $\mathrm{C} \rightarrow \mathrm{T}$ transition of the coding strand of the $A P C$ gene and vice versa. However, when we analysed tumours with a specific $\mathrm{C}: \mathrm{G} \rightarrow \mathrm{T}: \mathrm{A}$ mutation that leads to introduction of a stop codon, no significant association with meat products was found. This may be due to the limited group size. Moreover, we observed a large proportion of tumours to have multiple mutations, which further complicates analysis on specific types of mutations.

Consumption of other meat was associated with an increased risk of colon and rectal cancer. Other meat consisted of other meat eaten with the main course, i.e. horsemeat, lamb, mutton, frankfurters, and deep-fried meat rolls. The association was most pronounced in rectal tumours, and in both colon and rectal tumours without a truncating $A P C$ mutation. Although consumption of other meat was also positively associ- ated with rectal tumours with $\mathrm{C}: \mathrm{G} \rightarrow \mathrm{T}: \mathrm{A}$ transitions, irrespective of their putative effect, the observed associations were similar to rectal cancer without a truncating $A P C$ mutation, and may be due to chance. Although the intake of other meat is low, it seems that consumption of other meat is associated with an increased risk of colon and rectal cancer without a truncating $A P C$ mutation.

Beef consumption was associated with an increased risk of $A P C^{-}$colon tumours. In previous analyses on beef and $K$-ras mutation status within the same cohort beef was also positively associated with $\mathrm{K}$-ras ${ }^{-}$colon tumours [34]. A proportion of the $A P C^{-}$tumours harbour $A P C$ missense mutations. Analysis of tumours without a truncating mutation, but with a missense mutation and tumours that harboured neither of these mutations yielded similar results. When tumours with missense mutations and those without show similar incidence risk ratios, but different from tumours harbouring a truncating mutation, this suggest tumours with missense mutations may not be similar to tumours with impaired APC function. Possibly, the risk of beef consumption involves a pathway that does not involve inactivation of APC or activation of K-ras.

It has been suggested that the majority of colorectal cancer arises through the genetic pathway as described by Fearon and Vogelstein [8], which involves inactivation of the APC protein, generally followed by activation of the K-ras protein. Tumours that harbour mutations in the $A P C$ gene are generally chromosomally instable tumours [33]. A proportion of colorectal tumours may develop through different (epi-)genetic aberrations. MSI is such an alternative pathway and tumours showing MSI occur almost exclusively in the proximal colon. In a case-control study that addressed associations between dietary factors and MSI based on 40 microsatellite instable patients, an inverse association of red meat with microsatellite instable tumours was observed [25]. In 54 patients with hMLH1 deficient tumours in our study, no association with meat consumption was observed. This may indicate that the differences in observed associations may be due to the limited number of patients in both studies.

To our knowledge, this study is the first to have investigated the associations between meat, meat products and fish consumption and the occurrence of different types of $A P C$ mutations as well as expression of hMLH1 in a prospective cohort. Although most associations between meat, meat products and fish consumption are weak, our data suggest that several types of fresh meat and meat products seem to contribute differently to the aetiology of colon and rectal cancer, 
Table 4. Adjusted ${ }^{\mathrm{a}}$ incidence rate ratios (RR) and $95 \%$ CI for colon cancer patients lacking hMLH1 expression $(n=54)$ according to quartiles and categories intake of fresh meat, types of fresh meat, meat products, and fish

\begin{tabular}{|c|c|c|c|c|c|c|}
\hline & \multicolumn{2}{|c|}{ Median intake (g/day) } & \multirow[t]{2}{*}{ Person years } & \multicolumn{3}{|c|}{ Absent hMLH1 } \\
\hline & Men & Women & & $N$ cases & $\mathrm{RR}$ & $95 \% \mathrm{CI}$ \\
\hline \multicolumn{7}{|c|}{ Total fresh meat } \\
\hline 1 & 61 & 50.7 & 3533 & 14 & 1.00 & \\
\hline 2 & 91 & 80.3 & 3606 & 12 & 0.83 & $0.38-1.83$ \\
\hline 3 & 110.7 & 103.4 & 3561 & 16 & 1.11 & $0.53-2.33$ \\
\hline 4 & 150.8 & 139.2 & 3572 & 12 & 0.87 & $0.39-1.96$ \\
\hline$p$-trend & & & & & 0.95 & \\
\hline $1 \mathrm{SD}$ & & & & & 1.01 & $0.78-1.31$ \\
\hline \multicolumn{7}{|l|}{ Beef } \\
\hline 1 & 4.1 & 3 & 3561 & 10 & 1.00 & \\
\hline 2 & 16.1 & 14 & 3640 & 14 & 1.42 & $0.62-3.24$ \\
\hline 3 & 30 & 25.5 & 3557 & 15 & 1.45 & $0.64-3.27$ \\
\hline 4 & 51.4 & 46.9 & 3514 & 15 & 1.46 & $0.65-3.26$ \\
\hline$p$-trend & & & & & 0.37 & \\
\hline $1 \mathrm{SD}$ & & & & & 1.06 & $0.83-1.35$ \\
\hline \multicolumn{7}{|l|}{ Pork } \\
\hline 1 & 7.9 & 5 & 3497 & 17 & 1.00 & \\
\hline 2 & 28 & 22.5 & 3564 & 14 & 0.82 & $0.40-1.71$ \\
\hline 3 & 44.3 & 40.1 & 3569 & 12 & 0.69 & $0.32-1.48$ \\
\hline 4 & 76 & 66.2 & 3642 & 11 & 0.64 & $0.29-1.41$ \\
\hline$p$-trend & & & & & 0.67 & \\
\hline $1 \mathrm{SD}$ & & & & & 1.00 & $0.74-1.37$ \\
\hline \multicolumn{7}{|c|}{ Minced meat } \\
\hline 1 & 3.2 & 0 & 3525 & 10 & 1.00 & \\
\hline 2 & 11.5 & 9.6 & 3605 & 17 & 1.70 & $0.77-3.73$ \\
\hline 3 & 21 & 18.1 & 3605 & 15 & 1.61 & $0.71-3.66$ \\
\hline 4 & 37.8 & 32.9 & 3536 & 12 & 1.29 & $0.54-3.10$ \\
\hline$p$-trend & & & & & 0.63 & \\
\hline $1 \mathrm{SDs}$ & & & & & 1.02 & $0.83-1.27$ \\
\hline \multicolumn{7}{|l|}{ Liver } \\
\hline 1 & 0 & 0 & 9247 & 36 & 1.00 & \\
\hline 2 & 4.1 & 3.7 & 5025 & 18 & 0.99 & $0.55-1.80$ \\
\hline \multicolumn{7}{|c|}{ Other meat } \\
\hline 1 & 0 & 0 & 10098 & 42 & 1.00 & \\
\hline 2 & 6.6 & 7 & 4173 & 12 & 0.75 & $0.38-1.51$ \\
\hline \multicolumn{7}{|l|}{ Poultry } \\
\hline 1 & 0 & 0 & 3297 & 16 & 1.00 & \\
\hline 2 & 5.3 & 5.3 & 3464 & 13 & 0.78 & $0.38-1.64$ \\
\hline 3 & 13.2 & 13.2 & 3534 & 11 & 0.67 & $0.31-1.44$ \\
\hline 4 & 22.8 & 22.8 & 3978 & 14 & 0.72 & $0.34-1.50$ \\
\hline$p$-trend & & & & & 0.34 & \\
\hline $1 \mathrm{SD}$ & & & & & 0.93 & $0.69-1.27$ \\
\hline \multicolumn{7}{|c|}{ Meat products } \\
\hline 1 & 1 & 0 & 3444 & 15 & 1.00 & \\
\hline 2 & 7.4 & 4.3 & 3541 & 13 & 0.86 & $0.41-1.83$ \\
\hline 3 & 15.8 & 10.5 & 3682 & 12 & 0.75 & $0.34-1.66$ \\
\hline 4 & 33.3 & 22.4 & 3606 & 14 & 1.01 & $0.47-2.17$ \\
\hline$p$-trend & & & & & 0.92 & \\
\hline $1 \mathrm{SD}$ & & & & & 1.07 & $0.79-1.43$ \\
\hline \multicolumn{7}{|l|}{ Fish } \\
\hline 1 & 0 & 0 & 4089 & 15 & 1.00 & \\
\hline 2 & 4.6 & 4.6 & 3140 & 17 & 1.56 & $0.76-1.14$ \\
\hline 3 & 14.8 & 15.5 & 4318 & 15 & 0.94 & $1.02-1.17$ \\
\hline 4 & 30.5 & 28.2 & 2725 & 7 & 0.73 & $0.73-2.53$ \\
\hline$p$-trend & & & & & 0.37 & \\
\hline $1 \mathrm{SD}$ & & & & & 0.81 & $0.58-1.14$ \\
\hline
\end{tabular}

\footnotetext{
${ }^{a}$ Adjusted for age, sex, family history of colorectal cancer, smoking status, BMI, and energy intake.
} 
depending on the $A P C$ mutation status of the tumour, but not its hMLH1 expression status.

\section{Acknowledgements}

We are indebted to Prof. Dr. J.W. Arends and Dr. M. van Engeland for their participation in the initiation of this study. We would like to thank G. van Wijhe for laboratory assistance, Drs. A. Volovics and A. Kester for statistical advice; Dr. L. Schouten, S. van de Crommert, H. Brants, J. Nelissen, C. de Zwart, M. Moll, W. van Dijk, M. Jansen, and A. Pisters for assistance; and H. van Montfort, T. van Moergastel, L. van den Bosch, and R. Schmeitz for programming assistance. We also thank the participants of this study and wish to thank the regional cancer registries (IKA, IKL, IKMN, IKN, IKO, IKR, IKST, IKW, IKZ), and the Dutch nationwide network and registry of histo- and cytopathology (PALGA). Finally, we would like to thank the following hospitals for providing the tissue blocks: Academisch Ziekenhuis Nijmegen Sint Radboud, Academisch Ziekenhuis Groningen, Rijnland Ziekenhuis, Antoni van Leeuwenhoek Ziekenhuis, Academisch Ziekenhuis Rotterdam, Stichting Laboratorium Pathologie Oost Nederland, Pathologisch Instituut Utrecht, Ziekenhuis Rijnstate Arnhem, Laboratorium Volksgezondheid Leeuwarden, Ziekenhuis Bethesda, Stichting Samenwerkend Ziekenhuizen Oost Groningen, Martini Ziekenhuis Groningen, Samenwerkend Stichting Delftse Ziekenhuizen, Leyenburg Ziekenhuis, Academisch Ziekenhuis Vrije Universiteit, Academisch Medisch Centrum, Sint Franciscus Ziekenhuis, Dr. Daniel den Hoed Kliniek, Academisch Ziekenhuis Maastricht, Goudse Ziekenhuizen Stichting Laboratorium, Canisius Wilhelmina Ziekenhuis, Slootervaart Ziekenhuis, Maaslandziekenhuis, Atrium Heerlen, Atrium Kerkrade and Brunssum, Microbiologie St. Medische Stedendriehoek, IJsselmeer Ziekenhuizen, Ziekenhuis Centrum Apeldoorn, Isala Klinieken, Elkeriekziekenhuis, Groot Ziekengasthuis, Ziekenhuis Gooi Noord, Medisch Centrum Alkmaar, Regionaal Pathologisch en Cytologisch Laboratorium voor Eemland en Noord-West Veluwe, Diakonesse Ziekenhuis, Sint Antonius Ziekenhuis, Onze Lieve Vrouwe Gasthuis, St. Lucas Andreas Ziekenhuis, Pathologisch Anatomisch Laboratorium SPALK, Ziekenhuis de Heel, Diakonessenhuis, Rode Kruis Ziekenhuis, Ziekenhuis Bronovo, Laurentius Ziekenhuis Roermond, Pathologisch Anatomisch Laboratorium Dordrecht, Zuiderziekenhuis, Sint Clara Ziekenhuis, Medisch Centrum Haaglanden, St. Streeklaboratorium Zeeland, Sint Elisabeth Ziekenhuis, Catharinaziekenhuis, Sint Maartensgasthuis and Spaarne Ziekenhuis. This work was supported by the Netherlands
Organisation for Scientific Research and the Dutch Cancer Society.

\section{References}

1. Potter JD (1996) Nutrition and colorectal cancer. Cancer Causes Control 7(1): 127-146.

2. World Cancer Research Fund, American Institute for Cancer Research. Food, nutrition and the prevention of cancer: A global perspective. 1st ed. Washington, DC: WCRF/AIRC; 1997.

3. Norat T, Lukanova A, Ferrari P, Riboli E 2002Meat consumption and colorectal cancer risk: Dose-response meta- analysis of epidemiological studies 982241256.

4. Wei EK, Giovannucci E, Wu K, et al. (2004) Comparison of risk factors for colon and rectal cancer. Int J Cancer 108(3): 433442.

5. Iacopetta B. (2002) Are there two sides to colorectal cancer? Int $J$ Cancer 101(5): 403-408.

6. Brink M, De Goeij AF, Weijenberg MP, et al. (2003) K-ras oncogene mutations in sporadic colorectal cancer in The Netherlands Cohort Study. Carcinogenesis 24(4): 703-710.

7. Lüchtenborg M, Weijenberg MP, Roemen GM, et al. (2004) APC mutations in sporadic colorectal carcinomas from The Netherlands Cohort Study. Carcinogenesis 25(7): 1219-1226.

8. Fearon ER, Vogelstein B (1990) A genetic model for colorectal tumorigenesis. Cell 61(5): 759-767.

9. Powell SM, Zilz N, Beazer-Barclay Y, et al. (1992) APC mutations occur early during colorectal tumorigenesis. Nature 359(6392): 235-237.

10. Miyoshi Y, Nagase H, Ando H, et al. (1992) Somatic mutations of the APC gene in colorectal tumors: mutation cluster region in the APC gene. Human Mol Genet 1(4): 229-233.

11. Cottrell S, Bicknell D, Kaklamanis L, Bodmer WF (1992) Molecular analysis of APC mutations in familial adenomatous polyposis and sporadic colon carcinomas. Lancet 340(8820): 626630.

12. Miyaki M, Konishi M, Kikuchi-Yanoshita R, et al. (1994) Characteristics of somatic mutation of the adenomatous polyposis coli gene in colorectal tumors. Cancer Res 54(11): 3011-3020.

13. Yashima K, Nakamori S, Murakami Y, et al. (1994) Mutations of the adenomatous polyposis coli gene in the mutation cluster region: comparison of human pancreatic and colorectal cancers. Int J Cancer 59(1): 43-47.

14. Konishi M, Kikuchi-Yanoshita R, Tanaka K, et al. (1996) Molecular nature of colon tumors in hereditary nonpolyposis colon cancer, familial polyposis, and sporadic colon cancer. Gastroenterology 111(2): 307-317.

15. Filippo CDe, Luceri C, Caderni G, et al. (2002) Mutations of the APC gene in human sporadic colorectal cancers. Scand J Gastroenterol 37(9): 1048-1053.

16. Kim Sh SH, Kaminker P, Campisi J (2002) Telomeres, aging and cancer: in search of a happy ending. Oncogene 21(4): 503-511.

17. Diergaarde B, van Geloof WL, van Muijen GN, Kok FJ, Kampman E. (2003) Dietary factors and the occurrence of truncating APC mutations in sporadic colon carcinomas: a Dutch population-based study. Carcinogenesis 24(2): 283-90.

18. Olschwang S, Hamelin R, Laurent-Puig P, et al. (1997) Alternative genetic pathways in colorectal carcinogenesis. Proc Natl Acad Sci USA 94(22): 12122-12127.

19. Salahshor S, Kressner U, Pahlman L, Glimelius B, Lindmark G, Lindblom A. (1999) Colorectal cancer with and without microsatellite 
instability involves different genes. Genes Chromosomes Cancer 26(3) 247-252.

20. Samowitz WS, Holden JA, Curtin K, et al. (2001) Inverse relationship between Microsatellite Instability and K-ras and p53 Gene Alterations in Colon Cancer. Am J Pathol 158(4): 15171524.

21. Thibodeau SN, French AJ, Cunningham JM, et al. (1998) Microsatellite instability in colorectal cancer: different mutator phenotypes and the principal involvement of hMLH1. Cancer Res 58(8): 1713-8.

22. Toyota M, Ushijima T, Kakiuchi H, et al. (1996) Genetic alterations in rat colon tumors induced by heterocyclic amines. Cancer 77(8 Suppl): 1593-1597.

23. Bingham SA, Hughes R, Cross AJ (2002) Effect of white versus red meat on endogenous $\mathrm{N}$-nitrosation in the human colon and further evidence of a dose response. J Nutr 132(11 Suppl): 3522S$3525 \mathrm{~S}$.

24. Mirvish SS, Haorah J, Zhou L, Clapper ML, Harrison KL, Povey AC (2002) Total N-nitroso compounds and their precursors in hot dogs and in the gastrointestinal tract and feces of rats and mice: possible etiologic agents for colon cancer. $J$ Nutr 132(11 Suppl): 3526S-3529S.

25. Diergaarde B, Braam H, Muijen GNvan, Ligtenberg MJ, Kok FJ, Kampman E (2003) Dietary factors and microsatellite instability in sporadic colon carcinomas. Cancer Epidemiol Biomarkers Prev 12(11 Pt 1): 1130-1136.

26. van den Brandt PA, Goldbohm RA, van 't Veer P, Volovics A, Hermus RJ, Sturmans F (1990) A large-scale prospective cohort study on diet and cancer in The Netherlands. J Clin Epidemiol 43(3): 285-295.

27. van den Brandt PA, Schouten LJ, Goldbohm RA, Dorant E, Hunen PM (1990) Development of a record linkage protocol for use in the Dutch Cancer Registry for Epidemiological Research. Int J Epidemiol 19(3): 553-8.

28. Goldbohm RA, van den Brandt PA, van 't Veer P, et al. (1994) A prospective cohort study on the relation between meat consumption and the risk of colon cancer. Cancer Res 54(3): 718-723.

29. Goldbohm RA, van den Brandt PA, Brants HA, et al. (1994) Validation of a dietary questionnaire used in a large-scale prospective cohort study on diet and cancer. Eur J Clin Nutr 48(4): 253-265.

30. Lin DY, Wei LJ (1989) The robust inference for the Cox Proportional Hazards Model. JASA 84(408): 1074-1078.

31. Schoenfeld D (1982) Partial residuals for the proportional hazards regression models. Biometrika 69(1): 239-241.

32. Sandhu MS, White IR, McPherson K (2001) Systematic review of the prospective cohort studies on meat consumption and colorectal cancer risk: a meta-analytical approach. Cancer Epidemiol Biomarkers Prev 10(5): 439-446.

33. Fodde R, Smits R, Clevers H (2001) APC, signal transduction and genetic instability in colorectal cancer. Nat Rev Cancer 1(1): 55-67.

34. Brink M, Weijenberg MP, de Goeij AF, et al. (2005) Meat consumption and K-ras mutations in sporadic colon and rectal cancer in The Netherlands Cohort Study. Br J Cancer 92: 13101320 . 